\title{
Grafit- és grafénerősítésű sztirol-butadién kaucsuk fejlesztése
}

\section{Development of Graphite- and Graphene Reinforced Styrene-Butadiene Rubber}

\author{
Pirityi Dávid Zoltán, ${ }^{1}$ Pölöskei Kornél ${ }^{2}$ \\ Budapesti Müszaki és Gazdaságtudományi Egyetem, Gépészmérnöki Kar, Polimertechnika Tanszék, \\ Budapest, Magyarország \\ ${ }_{1}^{1}$ pirityid@pt.bme.hu \\ ${ }^{2}$ poloskei@pt.bme.hu
}

\begin{abstract}
The environmental impact of rubber waste can be reduced by extending the lifetime of rubber products. It can be achieved by developing graphene/rubber nanocomposites with good abrasion resistance. In this paper, we investigated how rubber mixing technologies influence the mechanical properties of rubber. We added various amounts $(0,1,5$ and $10 \mathrm{phr})$ of graphite and graphene to rubber mixtures using a tworoll mill, an internal mixer, a single- and a twin-screw extruder. We performed tensile, tear strength and Shore A hardness tests on the vulcanisates and analysed their fracture surfaces with a scanning electron microscope. Our results show that graphene had a better reinforcing effect than graphite. Rubber mixing via extrusion may contribute to more severe polymer degradation, though their reproducibility is better than that achieved on a two-roll mill or in an internal mixer.
\end{abstract}

Keywords: elastomer, graphite, graphene, nanocomposite.

\section{Összefoglalás}

A gumihulladékok környezetterhelése csökkenthető a gumitermékek élettartamának növelésével. Ennek egyik kitüntetett kutatási iránya a grafénnal erősített, nagy kopásállóságú nanokompozitok fejlesztése. Kutatásunk során a keverékkészítés technológiájának a gumi mechanikai tulajdonságaira gyakorolt hatását vizsgáltuk. Munkánk során 0, 1, 5 és 10 phr mennyiségben adalékoltunk grafitot és grafént gumikeverékekhez hengerszéken, zártkeverőben, egycsigás és ikercsigás extruderben. Az elkészített mintákon keménységmérést, szakító-, továbbszakító és elektronmikroszkópi vizsgálatot végeztünk. Vizsgálati eredményeink rávilágítottak arra, hogy a grafén jelentősebb erősítő hatást fejtett ki a grafitnál. Az extrúziós eljárások a polimer láncmolekulák nagyobb mértékű tördelődését okozhatják, igaz, reprodukálhatóságuk jobb, mint a hengerszéken vagy a zártkeverőben végzett keverékkészítésé.

Kulcsszavak: elasztomer, grafit, grafén, nanokompozit.

\section{Bevezetés}

A fejlődő környezetvédelmi normák egyre nagyobb nyomás alá helyezik az autóipart, hogy gumihulladékaik minél kisebb környezeti terhelést okozzanak. E terhelés csökkentésének két fő módját kutatják intenzíven: a) az anyagában történő újrahasznosítást (pl.: devulkanizálás [1, 2]) és b) az élettartam-növelést [3, 4]. Utóbbi megvalósíthatóságát támogathatja egy újszerű fejlesztési irány, amely során grafén nanorészecskéket adnak az autógumik futófelületét alkotó gumikeverékekhez [5]. 
A grafén a szén egyik allotrop módosulata, amelynek felfedezéséért Novoszjolov és Geim 2010-ben elnyerte a fizikai Nobel-díjat. Fajlagos felülete $\mathrm{kb} .2400 \mathrm{~m}^{2} / \mathrm{g}$, ami már kis mennyiségben történő adagolás esetén is lehetővé teszi kiemelkedő erősítő hatás elérését polimermátrixú kompozitokban [6].

A gumik rendkívül komplex anyagszerkezete miatt fontos, hogy azokat mindig holisztikus módon értékeljük. Lehetetlen egy időben minden mechanikai tulajdonság javítása, így komoly eredménynek tekinthető az is, ha bizonyos tulajdonságok releváns mértékben javulnak, de közben más mechanikai tulajdonságok csak oly mértékben csökkennek, hogy a termék alkalmazhatóságát nem befolyásolják [5].

Ebben a kutatásban a grafit és a grafén gumiipari alkalmazhatóságát és a keverékkészítés technológiájának hatásait vizsgáljuk.

\section{Kísérleti rész}

\subsection{Felhasznált anyagok}

A kutatás során sztirol-butadién kaucsuk (SBR) alapú keverékeket hoztunk létre, amelyek az autógumik futófelületét szimulálták. A gumikeverékek a következő alapanyagokat tartalmazták.

- SBR-kaucsuk: SKS-30 ARKPN SBR 1502 típusú, emulziós eljárással előállított SBR-kaucsuk (gyártó: Synthez Kauchuk JSC, Voronyezs, Oroszország);

- Korom: N330-as méretosztályú, amorf szén (gyártó: Kremenchug Carbon Black Plant, Kremencsuk, Ukrajna);

- Grafén (GR): xGnP Grade H típusú grafénrészecskék (gxártó: XG Sciences Inc., Lansing, Minnesota, USA);

- Grafit (G): C-Therm típusú, nagy fajlagos felületü, 1 mikron vastagságú grafitlemezkék (gyártó: Imerys Graphite \& Carbon, Bodio, Svájc).

A vulkanizálórendszer komponenseit, vagyis a cink-oxidot (ZnO), a sztearinsavat, az N-ciklohexil-2-benzotiazol-szulfenamidot (CBS), a tetrametil-tiurám-diszulfidot (TMTD) és a ként a Tauril Kft. szolgáltatta.

Az előkísérleteinkhez az 1. táblázatban bemutatott receptúrák alapján hoztunk létre kaucsukkeverékeket hengerszéken. Ennél a vizsgálati sornál az egycsigás extruder további keverőhatását vizsgáltuk 30 és 120 1/min csigafordulatszám mellett. Az így előállított minták elnevezései ebből adódtak. A minták jelöléseinek alsó indexében található „ee” az egycsigás extrudert, majd az azt követő szám a csigafordulatszámot jelöli. A minták elnevezésének végén az esetleges graféntartalmat jelenítettük meg a 100 tömegegység kaucsuktartalomra vonatkoztatva (phr, parts per hundred rubber): $\mathrm{SBR}_{\mathrm{ee} 30}, \mathrm{SBR}_{\mathrm{ee} 120}, \mathrm{SBR}_{\mathrm{ee} 30 \_\mathrm{GR} 1}$, SBR ${ }_{\text {ee120_GR1. }}$.

A fó kísérletek alapja egy 10 phr kormot és hatásos vulkanizálórendszert tartalmazó keverék, amelynek összetételét a 2 . táblázat tartalmazza. Ezeket a keverékeket is hengerszéken hoztuk létre, majd ikercsigás extruder vagy zártkeverő segítségével tovább kevertük. Az így létrehozott minták elnevezései is így adódtak. A „k” betű a koromtartalomra utal, utána az alsó index „ie” vagy „b” jele az ikercsigás extruderre és a zártkeverőre. A minták elnevezésének végén az esetleges grafén- (GR) vagy grafit- $(G)$ tartalmat jelöltük phr-ben: $\mathrm{kSBR}_{\mathrm{ie}}, \mathrm{kSBR}_{\mathrm{ie} \_\mathrm{GR} 1}, \mathrm{kSBR}_{\mathrm{ie} \_\mathrm{GR} 5}$, $\mathrm{kSBR}_{\mathrm{ie}_{\text {GGR10 }},}, \mathrm{kSBR}_{\mathrm{ie} \_\mathrm{G} 1}, \quad \mathrm{kSBR}_{\mathrm{ie}_{-} \mathrm{G} 5}, \mathrm{kSBR}_{\mathrm{ie} \_\mathrm{G} 10}$, $\mathrm{kSBR}_{\mathrm{b}}, \mathrm{kSBR}_{\mathrm{b}_{-} \mathrm{GR} 1}, \mathrm{kSBR}_{\mathrm{b}_{-} \mathrm{GR} 5}, \mathrm{kSBR}_{\mathrm{b}_{-} \mathrm{GR} 10}, \mathrm{kSBR}_{\mathrm{b}_{-} \mathrm{G} 1}$, $\mathrm{kSBR}_{\mathrm{b}_{-} \mathrm{G} 5}$ és $\mathrm{kSBR} \mathrm{b}_{\mathrm{b}_{-} \mathrm{G} 10}$.

1. táblázat. Az előkísérletekhez felhasznált SBR-keverékek

\begin{tabular}{|c|c|}
\hline Összetevő & phr \\
\hline SBR & 100 \\
\hline GR & $0 ; 1$ \\
\hline ZnO & 5 \\
\hline Sztearinsav & 1 \\
\hline CBS & 1 \\
\hline TMDT & 0,8 \\
\hline Kén & 2 \\
\hline
\end{tabular}

2. táblázat. A fó kísérletek gumireceptúrái

\begin{tabular}{|c|c|}
\hline Összetevő & phr \\
\hline SBR & 100 \\
\hline N330 & 10 \\
\hline GR & $0 ; 1 ; 5 ; 10$ \\
\hline G & $0 ; 1 ; 5 ; 10$ \\
\hline ZnO & 3,3 \\
\hline Sztearinsav & 2 \\
\hline CBS & 1,8 \\
\hline TMTD & 1,8 \\
\hline Kén & 1,7 \\
\hline
\end{tabular}




\subsection{Az alkalmazott eljárások}

A keverékkészítés első lépését Labtech LRMSC-110/T3E típusú hengerszéken végeztük. A mintákat 15 percig kevertük, a 3. táblázatban feltüntetett paramétereknek megfelelően.

Az előkísérletek során a hengerszéken előállított gumikeverékeket $10-20 \mathrm{~mm}$ széles csíkokra vágva adagoltuk egy Labtech LE 25-30/C típusú, egycsigás extruderbe. Az extrudálásra a grafén jobb elkeveredésére érdekében került sor. A homogenizálás minden előkísérleti minta esetében növekvő hőmérsékletprofil mellett valósult meg, az extruder behúzó szakaszát $80^{\circ} \mathrm{C}$-ra fütöttük fel, a szerszámot $100{ }^{\circ} \mathrm{C}$-ra.

A fő kísérletek során a hengerszékes keverést minden esetben ikercsigás extruderben vagy zártkeverőben történő keverés követte. Ehhez Labtech LTE 26-44 típusú, ikercsigás extrudert használtunk 60 1/min csigafordulatszámmal, növekvő hőmérsékletprofil mellett $\left(80^{\circ} \mathrm{C}\right.$ az extruder behúzó szakaszánál, $100{ }^{\circ} \mathrm{C}$ a szerszámnál). Az extruder behúzó szakasza A zártkeverőben történő homogenizálás Brabender Plasti-Corder típusú gépen történt. A keveréshez tangenciális rotorokat használtunk 65 1/min fordulatszámmal. A keverő $50 \mathrm{~cm}^{3}$-es kamráját $70{ }^{\circ} \mathrm{C}$-ra fütöttük, majd 70\%-ig töltöttük. A keverés addig tartott, amíg a kaucsukkeverék hőmérséklete elérte a $115^{\circ} \mathrm{C}$-t.

A homogenizálást követően a mintákat Collin Pressplate 200E típusú, hidraulikus présben vulkanizáltuk $160{ }^{\circ} \mathrm{C}$-on, $2,7 \mathrm{MPa}$ nyomáson, $\mathrm{t}_{90}$-ig (90\%-os vulkanizálási fokhoz tartozó ideig). A folyamat végén $2 \mathrm{~mm}$ vastag gumilapokat kaptunk. A gumilapokból golyós prés segítségével szakítóés továbbszakító próbatesteket vágtunk ki.

\subsection{Vizsgálati módszerek}

A gumikeverékek vulkanizálási paramétereit MonTech D-RPA 3000 típusú vulkaméterrel határoztuk meg. A vizsgálat során a gép egy vulkanizálatlan kaucsukkeverék próbatestet melegít fel $160{ }^{\circ} \mathrm{C}$-ra. Állandó $1,67 \mathrm{~Hz}$-es frekvenciát és $1^{\circ}$-os amplitúdót alkalmazva, az oszcilláló nyíró igénybevétel során folyamatosan mértük a szükséges forgatónyomatékot. A forgatónyomaték a modulus változásának megfelelően változik, ebből lehet következtetni a keresztkötések kialakulására, vagyis a vulkanizálás előrehaladására.

A szakítóvizsgálatokat Zwick Z020 típusú szakítógéppel, az ISO 37:2017 szabvány [7] szerint végeztük $500 \mathrm{~mm} / \mathrm{min}$ vizsgálati sebességgel, 60 mm-es befogási hosszról indítva. A továbbsza-
3. táblázat. A nyerskeverékek készítése során alkalmazott hengerszék-paraméterek

\begin{tabular}{|l|c|c|c|c|c|}
\hline & \multicolumn{2}{|c|}{$\begin{array}{c}\text { Fordulatszám } \\
(\mathbf{1} / \mathbf{m i n})\end{array}$} & \multicolumn{2}{|c|}{$\begin{array}{c}\text { Hőmérséklet } \\
\left({ }^{\circ} \mathbf{C}\right)\end{array}$} & $\begin{array}{c}\text { Rés- } \\
\text { méret } \\
(\mathbf{m m})\end{array}$ \\
\hline Henger: & $\mathbf{1 .}$ & $\mathbf{2 .}$ & $\mathbf{1 .}$ & $\mathbf{2 .}$ & $\mathbf{2}$ \\
\hline 0-5 perc & 3 & 5 & 50 & 70 & 2 \\
\hline 5-10 perc & 5 & 8 & 50 & 70 & 0,75 \\
\hline 10-15 perc & 10 & 15 & 50 & 70 & 0,75 \\
\hline
\end{tabular}

4. táblázat. Az előkísérletek szakítóvizsgálatának eredményei

\begin{tabular}{|l|c|c|}
\hline \multicolumn{1}{|c|}{ Minta } & $\begin{array}{c}\text { Szakítószilárd- } \\
\text { ság (MPa) }\end{array}$ & $\begin{array}{c}\text { Szakadási nyúl- } \\
\text { ás (\%) }\end{array}$ \\
\hline $\mathrm{SBR}_{\mathrm{e} \text { 30 }}$ & $1,65 \pm 0,05$ & $114,3 \pm 7,0$ \\
\hline $\mathrm{SBR}_{\mathrm{e} 30 \_G R 1}$ & $2,71 \pm 0,12$ & $181,9 \pm 9,4$ \\
\hline $\mathrm{SBR}_{\mathrm{ee} 120}$ & $2,08 \pm 0,18$ & $164,0 \pm 9,7$ \\
\hline $\mathrm{SBR}_{\mathrm{ee} 120 \_G R 1}$ & $2,30 \pm 0,20$ & $158,4 \pm 16,3$ \\
\hline
\end{tabular}

5. táblázat. Az előkísérleti minták továbbszakító szilárdsága

\begin{tabular}{|l|c|}
\hline \multicolumn{1}{|c|}{ Minta } & $\begin{array}{c}\text { Továbbszakító szilárdság } \\
(\mathbf{N} / \mathbf{m m})\end{array}$ \\
\hline $\mathrm{SBR}_{\mathrm{e} 30}$ & $4,15 \pm 0,17$ \\
\hline $\mathrm{SBR}_{\mathrm{e} 3030 \mathrm{GR} 1}$ & $4,29 \pm 0,26$ \\
\hline $\mathrm{SBR}_{\mathrm{ee} 120}$ & $4,40 \pm 0,30$ \\
\hline $\mathrm{SBR}_{\mathrm{ee} 120 \_G R 1}$ & $5,16 \pm 0,38$ \\
\hline
\end{tabular}

kító vizsgálatok során ugyanazon a berendezésen, az ISO 34-1:2015 szabványt [8] alkalmaztuk: $500 \mathrm{~mm} / \mathrm{min}$ vizsgálati sebesség és $56 \mathrm{~mm}$ befogási hossz mellett. A továbbszakító próbatesteken $1 \mathrm{~mm}$-es bemetszést ejtettünk, hogy azok a kívánt helyen szakadjanak el.

A szakítóvizsgálatokat követően a próbatestek töretfelületéről JEOL JSM 6380LA típusú pásztázó elektronmikroszkóppal készítettünk felvételeket.

A Shore keménységmérést Zwick H04.3150 típusú berendezéssel, az ISO 48-4:2018 szabvány [9] szerint, mintánként 10-10 pontban mérve végeztük el.

\section{Eredmények}

\subsection{Előkísérletek}

A szakítóvizsgálat eredményei a 4. táblázatban, a továbbszakító vizsgálatok eredményei az 5. táblázatban találhatók. 30 1/min csigasebesség ese- 
tén látható a felhasznált 1 phr grafén erősítő hatása: mind a szakítószilárdság, mind a szakadási nyúlás kb. 60\%-kal növekedett a töltetlen mintához képest. A magasabb fordulatszám a töltetlen keverék tulajdonságaira kedvezően hatott, míg az SBRee120_GR1 szakadási tulajdonságai elmaradtak a 30 1/perccel kevert mintáéhoz képest. A továbbszakító szilárdságra mind a graféntartalom, mind a magasabb fordulatszám pozitív hatással volt, vagyis a gumi repedésterjedéssel szembeni ellenállását ezek növelik.

Pásztázó elektronmikroszkópi felvételek (1. ábra) alapján úgy becsültük, hogy az extrúzió során a grafén részecskemérete nem változott, annak eloszlatottsága, illetve a polimermolekulák darabolódása okozhatta a vizsgált mechanikai tulajdonságok változását.

\subsection{Az ikercsigás extrúzió és a zártkeverő- vel történő keverés összehasonlítása}

A fő kísérletek során az ikercsigás extruderrel és a zártkeverővel végzett keverés hatásait hasonlítottuk össze. Először a vulkanizálási tulajdonságokat vizsgáltuk. A 2. ábrán az ikercsigás extruderrel előállított minták vulkanizálási görbéit ábrázoltuk, a 3. ábrán pedig a zártkeverővel előállított minták görbéit. A 2. ábra alapján megfigyelhető, hogy a fellépő forgatónyomaték (S’) minimális és maximális értékei is növekedtek az erősítőanyag mennyiségének növelésével. Vagyis a minták nyíró modulusa az adalékok hozzáadásának következtében megnőtt. A 90\%-os térhálósodás ideje $\left(\mathrm{t}_{90}\right)$ az adalékanyagok hozzáadásával jelentősen lecsökkent, a 10 phr grafént tartalmazó minta esetén $20 \%-k a l$ a töltetlen referenciakeverékéhez képest.

A 3. ábrán láthatjuk, hogy a zártkeverőben előállított minták vulkanizációs görbéi között nagyobb az eltérés, mint az extruderrel előállított minták között. A kSBR $_{\mathrm{b}_{\mathrm{G}} \mathrm{G10}}$ maximális nyomatékértéke kiugróan kicsi. A vulkaméteren mért maximális nyomatékérték általában a minták keménységével és modulusával korreláló menynyiség. A kSBR $\mathrm{b}_{\mathrm{G} 10}$ vulkanizációs görbéje alapján arra számítottunk, hogy a minta keménysége (5. ábra) is kisebb, mint a többi mintáé; valójában ez a minta a legkeményebb a zártkeverőben előállított keverékek közül.

A szakítóvizsgálatok során a grafit és a grafén erősítőhatása közötti különbségre, valamint a tulajdonságok töltőanyag-tartalomtól való függésére kerestük a választ. A szakítóvizsgálatból meghatározott jellemzőket a 6. és 7. táblázat tartalmazza.
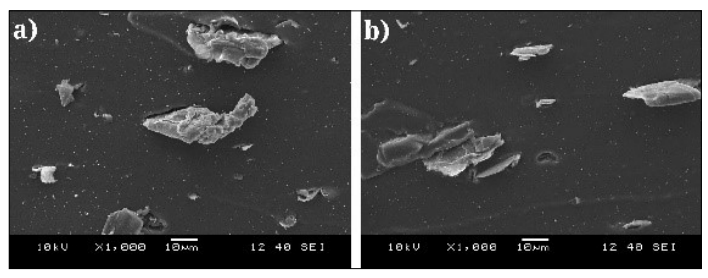

1. ábra. Pásztázó elektronmikroszkópi felvételek az előkísérleti minták szakadási töretfelületérôl: a) $S B R_{e e 30 \_G R 1}$ b) $S B R_{e e 120 \_G R 1}$

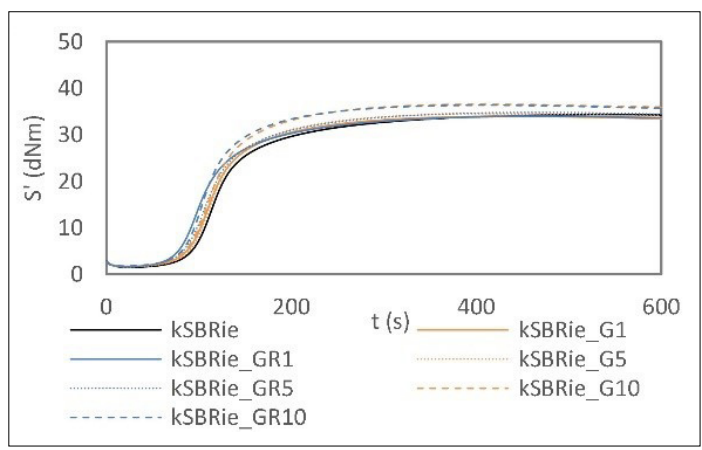

2. ábra. Az ikercsigás extruderrel előállított keverékek vulkanizációs görbéi

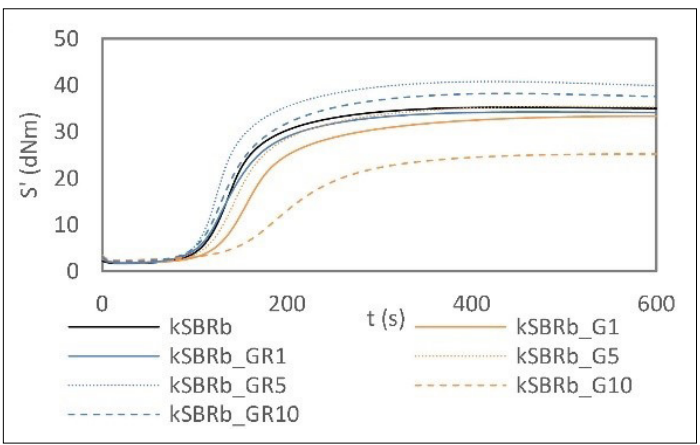

3. ábra. A zártkeverőben előállított keverékek vulkanizációs görbéi

6. táblázat. Az ikercsigás extruderrel elöállított minták szakítóvizsgálati eredményei

\begin{tabular}{|l|c|c|}
\hline \multicolumn{1}{|c|}{ Minta } & $\begin{array}{c}\text { Szakítószilárd- } \\
\text { ság (MPa) }\end{array}$ & $\begin{array}{c}\text { Szakadási nyúlás } \\
\text { (\%) }\end{array}$ \\
\hline $\mathrm{kSBR}_{\text {ie }}$ & $2,87 \pm 0,08$ & $120,5 \pm 4,1$ \\
\hline $\mathrm{kSBR}_{\text {ie_GR1 }}$ & $3,30 \pm 0,31$ & $128,8 \pm 4,5$ \\
\hline $\mathrm{kSBR}_{\text {ie_GR5 }}$ & $2,75 \pm 0,09$ & $114,7 \pm 1,0$ \\
\hline $\mathrm{kSBR}_{\text {ie_GR10 }}$ & $3,82 \pm 0,30$ & $125,1 \pm 5,8$ \\
\hline $\mathrm{kSBR}_{\text {ie_G1 }}$ & $2,57 \pm 0,17$ & $108,9 \pm 8,2$ \\
\hline $\mathrm{kSBR}_{\text {ie_G5 }}$ & $2,88 \pm 0,16$ & $111,5 \pm 1,8$ \\
\hline $\mathrm{kSBR}_{\text {ie_G10 }}$ & $3,24 \pm 0,19$ & $115,3 \pm 2,1$ \\
\hline
\end{tabular}


7. táblázat. A zártkeverővel előállított minták szakítóvizsgálati eredményei

\begin{tabular}{|l|c|c|}
\hline \multicolumn{1}{|c|}{ Minta } & $\begin{array}{c}\text { Szakítószilárd- } \\
\text { ság (MPa) }\end{array}$ & $\begin{array}{c}\text { Szakadási nyúlás } \\
\text { (\%) }\end{array}$ \\
\hline $\mathrm{kSBR}_{\mathrm{b}}$ & $1,60 \pm 0,03$ & $79,6 \pm 7,2$ \\
\hline $\mathrm{kSBR}_{\mathrm{b} \_\mathrm{GR} 1}$ & $1,27 \pm 0,06$ & $65,3 \pm 10,6$ \\
\hline $\mathrm{kSBR}_{\mathrm{b} \_\mathrm{GR} 5}$ & $3,05 \pm 0,06$ & $92,6 \pm 4,9$ \\
\hline $\mathrm{kSBR}_{\mathrm{b} \_\mathrm{GR} 10}$ & $3,96 \pm 0,08$ & $162,5 \pm 18,6$ \\
\hline $\mathrm{kSBR}_{\mathrm{b} \_\mathrm{G} 1}$ & $1,76 \pm 0,04$ & $93,2 \pm 6,7$ \\
\hline $\mathrm{kSBR}_{\mathrm{b} \text { G5 }}$ & $2,49 \pm 0,07$ & $91,8 \pm 2,0$ \\
\hline $\mathrm{kSBR}_{\mathrm{b}_{\text {_G }}}$ & $2,54 \pm 0,08$ & $76,4 \pm 1,9$ \\
\hline
\end{tabular}

Az ikercsigás extrúzió esetén (6. táblázat) elmondható, hogy a grafénnel jobb eredményeket lehet elérni, mint a grafittal. Az 1 phr grafént tartalmazó minta szakítószilárdsága közel azonos értékű, mint a 10 phr grafitot tartalmazó mintáé. Szakítószilárdság tekintetében a 10 phr grafént tartalmazó keverék teljesített a legjobban: 30\%-os javulást ért el a töltetlen keverékhez képest.

A zártkeverővel előállított minták szakítóvizsgálati eredményeit a 7. táblázatban foglaltuk össze. E minták többségének szakadási nyúlása nem éri el a 100\%-ot. Egyetlen kivételt képez a 10 phr graféntartalmú minta, amely 160\%-os szakadási nyúlásával kiemelkedik mind a zártkeverővel, mind az ikercsigás extruderrel készített minták közül.

A 4. ábrán az ikercsigás extruderrel és a zártkeverőben homogenizált minták továbbszakító szilárdságát ábrázoltuk az adaléktartalom függvényében. A zártkeverőben homogenizált minták értékei rendre nagyobbak az extrudált mintákéhoz képest. Ez alátámasztja azt a feltevést, hogy az extruderben fellépő nagy nyírás a polimerláncok szakadásához vezet.

Az előállított minták Shore-keménységét az adaléktartalom függvényében az 5. ábrán öszszegeztük. Egyértelmű trendként figyelhető meg, hogy a hozzáadott adalékanyagok növelik a nanokompozitok keménységét. Eljárástól és az erősítés típusától függetlenül kb. megegyező értékeket mértünk azonos összetétel esetén. Kiugró kivételt képez az ikercsigás extruderrel előállított töltetlen keverék, amelynek 61,3×0,7 Shore A keménysége meghaladja az 5 phr adaléktartalmú minták keménységét.

A pásztázó elektronmikroszkópi vizsgálat feltárta a kompozit mikroszerkezetét; az ezt szemléltető képeket a 6 . ábrán mutatjuk be. A felvételeket

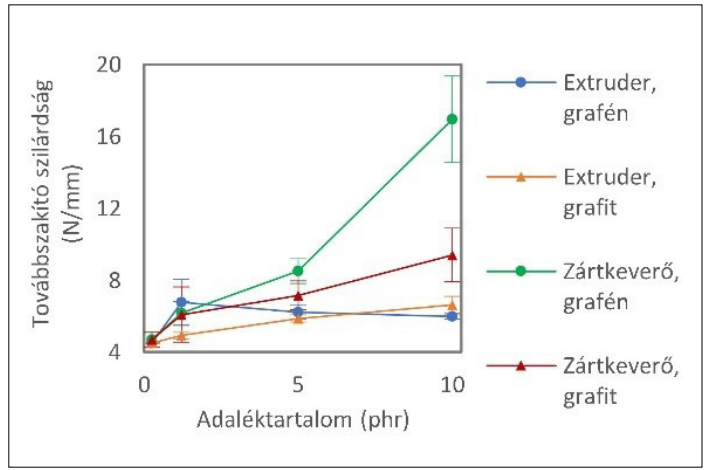

4. ábra. Nanokompozit-minták továbbszakító szilárdsága az adaléktartalom függvényében

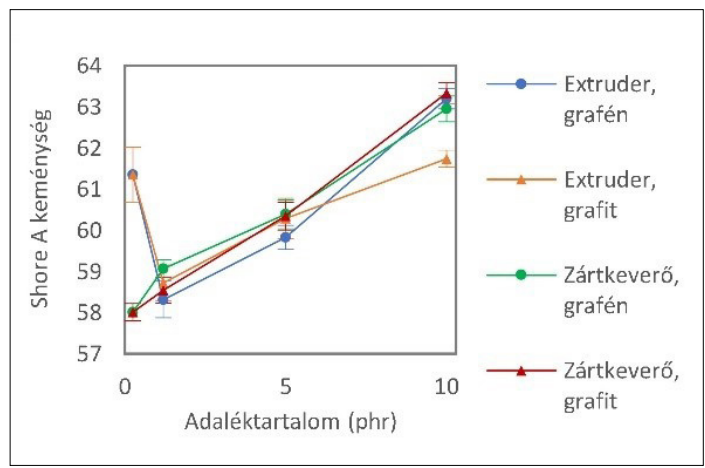

5. ábra. Nanokompozit-minták Shore A keménysége az adaléktartalom függvényében
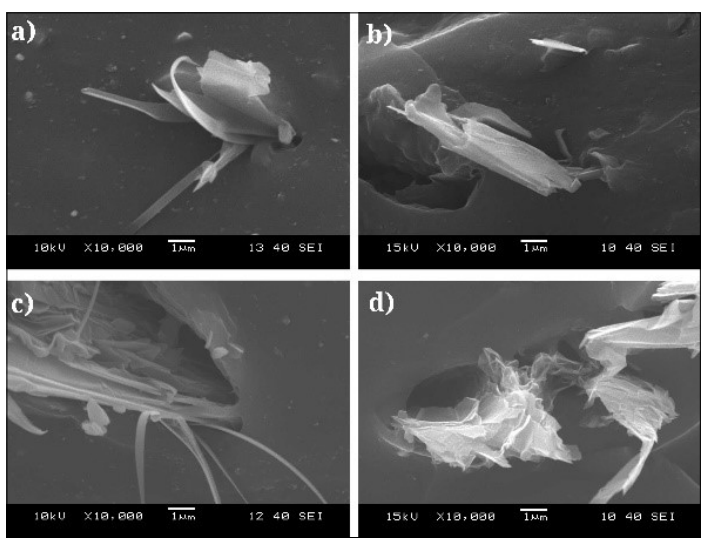

6. ábra. Pásztázó elektronmikroszkópi felvételek az előállított kompozitok szakadási töretfelületeiről: a) $\left.\left.k S B R_{i e_{-} G R 10}, b\right) k S B R_{b_{-} G R 10}, c\right) k S B R_{i e_{-}}$ $G 10, d) k S B R_{b_{-} G 10}$

úgy választottuk ki, hogy a töretfelületre leginkább jellemző részleteket mutassuk be. A grafit és a grafén is jól láthatóan lemezes szerkezetü, a különbséget a lemezek száma jelenti. A felvétele- 
ken látható, hogy a grafit lényegesen több rétegű, és a próbatest tönkremenetele során maga is alakváltozhatott. Ezzel szemben a grafén látszólagosan megőrizte a kiindulási szerkezetét, ezek a részecskék a mátrixból kiemelkedve maradtak a felületen. Az ikercsigás extruderrel homogenizált mintákról készült felvételeken láthatók vékony, hosszúkás, az adalék szemcséiből induló fibrillák, amelyek nagy fajlagos felületükkel erős adhézió kialakítását tették lehetővé az alapmátrixszal. Mind a grafénnel, mind a grafittal töltött minták esetén az ikercsigás extruderrel előállított mintákban váltak szét sikeresebben az adalékok részecskéi.

\section{Következtetések}

Előkísérleteink során bebizonyosodott, hogy a grafén már kis mennyiségben (1 phr) is jelentős mechanikaitulajdonság-javulást eredményez.

Fő kísérleteink segítségével bemutattuk, hogy az ikercsigás extrúzióval jobb adalékeloszlatást értünk el, mint a zártkeverővel végzett keverékkészítéssel. Ennek ellenére mégis a zártkeverőben készített minták továbbszakító szilárdsága és keménysége a nagyobb. Az eltérésből arra következtetünk, hogy az ikercsigás extrúzió során az intenzívebb nyíró igénybevétel hatására a molekulatömeg lecsökkent.

Kijelenthetjük, hogy a grafénerősítésű gumik fejlesztésében nagy potenciál van. A keverékkészítéshez alkalmazott eljárások hatásmechanizmusait mélyebben fel kell tárni az egyértelműbb következtetésekhez.

\section{Köszönetnyilvánítás}

A kutatás a Nemzeti Kutatási, Fejlesztési és Innovációs Hivatal támogatásának jóvoltából valósult meg a 2017-2.3.6-TÉT-CN-2018-00002 számú ipari kutatás-fejlesztési együttműködési pályázat keretein belül. Ezúton köszönjük Móritz Szilviának a mérések során nyújtott segítséget.

\section{Szakirodalmi hivatkozások}

[1] Formela K., Hejna A., Zedler Ł., Colom X., Cañavate J.: Microwave treatment in waste rubber recycling - recent advances and limitations. Express Polymer Letters, 13. (2019) 565-588.

https://doi.org/10.3144/expresspolymlett.2019.48

[2] Kaewpetch B., Prasongsuk S., Poompradub S.: Devulcanization of natural rubber vulcanizates by Bacillus cereus TISTR 2651. Express Polymer Letters, 13. (2019) 877-888.

https://doi.org/10.3144/expresspolymlett.2019.76

[3] Cao L., Sinha T. K., Tao L., Li H., Zong C., Kim J. K.: Synergistic reinforcement of silanized silica-graphene oxide hybrid in natural rubber for tire-tread fabrication: A latex based facile approach. Composites Part B: Engineering, 161. (2019) 667-676.

https://doi.org/10.1016/j.compositesb.2019.01.024

[4] Hajba S., Tábi T.: Cross effect of natural rubber and annealing on the properties of poly(lactic acid). Periodica Polytechnica Mechanical Engineering, 63. (2019) 270-277. https://doi.org/10.3311/PPme.12825

[5] Guo H., Ji P., Halász I. Z., Pirityi D. Z., Bárány T., Xu Z., Zheng L., Zhang L., Liu L., Wen S.: Enhanced fatigue and durability properties of natural rubber composites reinforced with carbon nanotubes and graphene oxide. Materials, 13. (2020) 5746. https://doi.org/10.3390/ma13245746

[6] Berki P., László K., Tung N. T., Karger-Kocsis J.: Natural rubber/graphene oxide nanocomposites via melt and latex compounding: Comparison at very low graphene oxide content. Journal of Reinforced Plastics and Composites, 36. (2017) 808-817. https://doi.org/10.1177/0731684417690929

[7] ISO 37:2017: Rubber, vulcanized or thermoplastic - Determination of tensile stress-strain properties, 2017.

[8] ISO 34-1:2015: Rubber, vulcanized or thermoplastic - Determination of tear strength - Part 1: Trouser, angle and crescent test pieces, 2015.

[9] ISO 48-4:2018: Rubber, vulcanized or thermoplastic - Determination of hardness - Part 4: Indentation hardness by durometer method (Shore hardness), 2018. 